\title{
Response of Forsythia $\times$ itermedia 'Spectabilis' to Uniconazol. I. Growth; Dry-matter Distribution; and Mineral Nutrient Content, Concentration, and Partitioning
}

\author{
Mack Thetford ${ }^{1}$, Stuart L. Warren ${ }^{2}$, and Frank A. Blazich ${ }^{3}$ \\ Department of Horticultural Science, North Carolina State University, Raleigh, NC 27695-7609
}

Additional index words. sumagic, plant growth retardant, triazole, gibberellin biosynthesis inhibitor

\begin{abstract}
Uniconazole was applied as a foliar spray at $0,90,130,170$, or $210 \mathrm{mg} \cdot l i t e r^{-1}$ to rooted stem cuttings of 'Spectabilis' forsythia (Forsythia xintermedia Zab.) potted in calcined clay. Plants were harvested 0, 40, 80, 120, and 369 days after

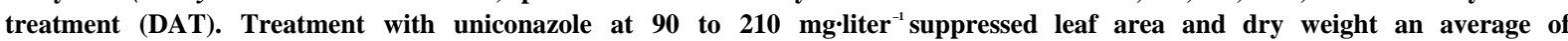
$16 \%$ and $18 \%$, respectively, compared to the nontreated controls when averaged over all harvest periods. Stem and root dry weight suppression was greatest at 80 DAT, $47 \%$ and $37 \%$, respectively. Uniconazole suppressed root length from $15 \%$ to $36 \%$ and root area from $15 \%$ to $33 \%$ depending on harvest date. Internode length and stem diameter of uniconazole-treated plants were suppressed at all harvests except 369 DAT. Uniconazole resulted in increased and decreased root : shoot ratios 40 and 80 DAT, respectively; while root : shoot ratios were not affected for the remainder of the study. Relative growth rates of leaves, stems, and roots decreased with increasing uniconazole concentration; however, no relative growth rates were suppressed beyond 80 DAT. Generally, mineral nutrient concentrations increased as a result of uniconazole application. The proportion of mineral nutrients allocated to leaves and roots was not affected while the proportion of nutrients allocated to stems decreased with uniconazole application compared to the controls. Chemical name used: (E)-1-(p-chlorophenyl)-4,4-dimethyl-2-(1,2,4-triazol-1-yl)-1-penten-3-ol (uniconazole).
\end{abstract}

Increasing costs and restrictions on disposal of organic wastes in landfills has stimulated interest in the use of plant growth retardants to limit vegetative growth and reduce pruning frequency of woody landscape plants. Research has demonstrated the potential use of uniconazole (Valent U.S.A., Walnut Creek, Calif.), as an economical method of reducing plant growth in established landscape plantings (Keever and West, 1992) or as a component of container production regimes for woody landscape species (Norcini and Knox, 1989; Warren 1990; Warren et al., 1991).

Uniconazole is a member of a group of compounds known as triazoles which retard growth of several ornamental species (Bailey and Miller, 1989; Keever and West, 1992; Norcini and Knox, 1989; Wang and Gregg, 1989; Warren 1990). Triazoles are xylem mobile and when applied to roots, young stems, and to a lesser extent the youngest leaves, are absorbed and translocated acropetally to the leaves (Reed et al., 1989; Sterrett, 1988). Uniconazole limits plant growth by inhibiting gibberellin biosynthesis (Izumi et al., 1984). Several effects other than suppression of shoot growth have also been reported and include suppressed leaf area, altered root morphology and physiology, and altered root : shoot ratios (Davis et al., 1988).

Conflicting results have been reported concerning changes in root growth following application of paclobutrazol (another triazole compound) as a foliar spray or in a nutrient solution to tree fruits.

Received for publication 16 Dec. 1994. Accepted for publication 8 May 1995. This research was funded by the North Carolina Agricultural Research Service (NCARS), Raleigh, NC 27695-7643. Use of trade names in this publication does not imply endorsement by the NCARS of products named nor criticism of similar ones not mentioned. Uniconazole was provided by Valent U.S.A., Walnut Creek, Calif. Technical assistance of William M. Reece and the Analytical Service Laboratory, Dept. of Soil Science, is gratefully acknowledged. This paper is based on a PhD thesis by M.T. The cost of publishing this paper was defrayed in part by the payment of page charges. Under postal regulations, this paper therefore must be hereby marked advertisement solely to indicate this fact.

'Former graduate teaching assistant. Currently assistant professor, Univ. of Florida, 5988 Hwy. 90 W., Bldg. 4900, Milton, FL 32583.

${ }^{2}$ Associate professor.

${ }^{3}$ Professor
Foliar application of paclobutrazol resulted in increased root tip diameter and decreased nonsuberized root length of 'Redhaven' peach [Prunus persica (L.) Batsch] grown in a commercial potting mix (Williamson et al., 1986) while similar responses were not evident with 'Nemaguard' peach rootstock $[P$. persica $\times$ Prunus davidiana (Carrie're) Franch.] following continuous paclobutrazol exposure in nutrient solution culture (Rieger and Scalabrelli, 1990). In addition, foliar application of paclobutrazol increased weight, diameter, and length of fibrous roots of seedlings of apple (Malus domestica Borkh.) (Steffens et al., 1983). Such changes may also affect water and mineral nutrient uptake since these processes occur principally through nonsuberized portions of young roots.

Research with paclobutrazol involving root zone or bark application to tree fruits suggests this compound can alter mineral nutrient status. Mineral nutrient content and concentration responses, however, differed with the species tested and method of application (Atkinson, 1986; Atkinson and Crisp, 1982; Rieger and Scalabrelli, 1990; Swietlik and Miller, 1985; Wang et al., 1985; Wieland and Wample, 1985). Currently, little information is available concerning the effects of triazoles on root growth of woody landscape species (Reed et al., 1989) or the effects root system alteration may have on mineral nutrient status of such plants.

While these above mentioned reports provide useful information about the effectiveness of uniconazole following a soil or potting medium application or inclusion within a nutrient solution culture, these application methods allow continuous exposure to uniconazole through root uptake. Triazoles can be quite persistent with growth retardant effects occurring on plants that were grown on soil treated the previous year (Fletcher and Hofstra, 1985); an undesirable characteristic for plants destined for the landscape. There also exists major differences in effectiveness among the gibberellin biosynthesis inhibitors which result in differences in longevity of effect and extent of inhibition; uniconazole is more effective than paclobutrazol, flurprimidol, and triadimefon in reducing growth (Steffens, 1988). Before uniconazole can be incorporated into a production or maintenance regime, a better 
understanding of how the product may affect other production or maintenance practices is needed. Previous research has demonstrated vigorous shoot growth of 'Spectabilis' forsythia can be suppressed with foliar (leaf and stem) application of uniconazole, but this work did not consider the effect uniconazole may have on root growth (Warren et al., 1991). Therefore, the objectives of this research were to determine if 1) uniconazole-induced shoot suppression is accompanied by root growth suppression with subsequent changes or alterations in dry matter distribution between roots and shoots, and 2) uniconazole application influences mineral nutrient content, concentration, and partitioning within 'Spectabilis' forsythia.

\section{Materials and Methods}

Experiment 1 (first outdoor container study). Rooted stem cuttings of 'Spectabilis' forsythia were potted on 14 May 1991 into 3.8 liter containers with arcillite, a calcined clay substrate (Aimcor Inc., Deerfield, Ill.) and placed on a gravel container pad at the Horticulture Field Laboratory, Raleigh. Arcillite was selected as a substrate to allow complete recovery of intact root systems at harvest. Uniconazole (500 mg.liter ${ }^{-1}$ solution formulation) at 0,90 , 130,170, or $210 \mathrm{mg} \cdot \mathrm{liter}^{-1}$ was applied to forsythia on 13 June 1991 between 7:00 AM and 8:30 AM with a hand held sprayer to uniformly wet all leaves and stems (12 to $15 \mathrm{ml}$ per plant). These concentrations were chosen on the basis of results of previous experiments which evaluated the effectiveness of a $500 \mathrm{mg} \cdot \mathrm{liter}^{-1}$ solution and a 30\% WP formulation of uniconazole as a spray or drench application, respectively (Warren, 1990; Warren et al., 1991). Each container was fitted with a cardboard collar to prevent uniconazole from dripping off the shoots onto the substrate; collars were removed from the containers after the spray applications had dried. Climatic conditions at the time of treatment were clear skies, a dry bulb temperature of $20.8 \mathrm{C}$, dewpoint of $17.4 \mathrm{C}$, and no wind.

The experimental design was a split-plot with four replicates assigned to blocks based on initial primary stem number, leaf area (visual assessment), and plant height $(12$ to $15 \mathrm{~cm}$ ). Uniconazole concentrations were randomly allocated to main plots and five harvest dates of $0,40,80,120$, and 369 days after treatment (DAT) were randomly allocated to subplots within each main plot. The first harvest (0 DAT) consisted of 20 plants (one plant per treatment per replication) and all subsequent harvests consisted of 40 plants [two plants (subsamples) per treatment per replication]. Plants were rearranged following each destructive harvest to provide equal spacing between all plants and a guard row of plants was included around the perimeter of the experimental plants.

Plants were maintained under drip irrigation applied twice daily at about $500 \mathrm{ml}$ per container per application. Beginning 16 May 1991, plants were fertilized twice weekly with $500 \mathrm{ml}$ of a nutrient solution containing $200 \mathrm{mg} \cdot \mathrm{liter}^{-1} \mathrm{~N}$ from a $20 \mathrm{~N}-4.3 \mathrm{P}-16.6 \mathrm{~K}$ water soluble fertilizer (Peters 20-10-20 Peat Lite Special; Grace/ Sierra, Fogelsville, Pa.). The solution also contained $15 \mathrm{mg} \cdot \mathrm{liter}^{-1} \mathrm{Ca}$ provided by $\mathrm{CaSO}_{4} \cdot 2 \mathrm{H}_{2} \mathrm{O}$. Fertilization was reduced to a weekly application $(500 \mathrm{ml})$ beginning 28 Sept., and discontinued after 19 Oct. Plants were placed in an overwintering structure covered with white copolymer plastic in Nov. 1991 and the covering was removed in Feb. 1992 when flowering began. Following resumption of growth, each pot was top dressed with $18 \mathrm{~g} 16 \mathrm{~N}-2.6 \mathrm{P}-8.3 \mathrm{~K}$ Osmocote (12-14 month, 16-6-10 + minors, Grace/Sierra Chemical Co., Milpitas, Calif.) on 6 Apr. 1992.

Length and diameter of the fourth visible internode from a single stem apex of each plant were measured at each harvest using an electronic digital caliper (Max-Cal; Fowler \& NSK, Japan).
Leaf area (entire plant) was determined at each harvest with a leaf area meter (LI-3000; LI-COR, Lincoln, Neb.). Stems and roots were separated after washing the substrate from the root systems.

A subsampling technique was developed to estimate total root area and total root length of the extensive, highly branched root systems. At 40 DAT, root length and area of the entire root system and a root subsample were determined from 11 additional nontreated plants from within the guard rows. Each root subsample consisted of two roots originating from the root collar (stem-root junction). Prior to measurement, all roots were weighed and then soaked in $1 \%$ methylene blue for $48 \mathrm{~h}$. Root area and root length were measured with an image analyzer (Digital Image Analysis System; Decagon Devices, Inc., Pullman, Wash.). Root subsample and root fresh weights were then used to estimate total root area and total root length.

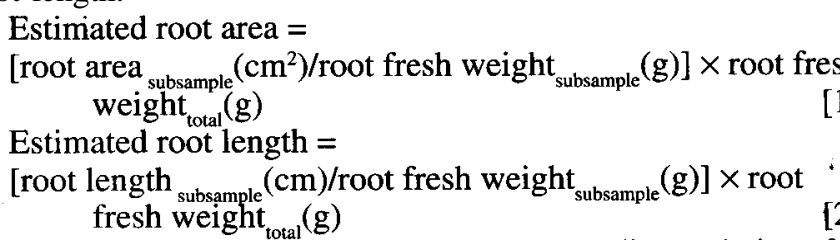

To determine the ability-of the root subsampling technique for estimating actual total root length and total root area, estimated root area was regressed on actual root area and estimated root length was regressed on actual root length resulting in the following linear equations:

Actual total root area $\left(\mathrm{cm}^{2}\right)=$

$2499.3+(0.920 \times$ estimated total root area $), R^{2}=0.90$

Actual total root length $(\mathrm{cm})=$

$2470.0+(0.678 \times$ estimated total root length $), R^{2}=0.90$ Since coefficient of determination $\left(R^{2}\right)$ values were high, it was possible to predict total root area and total root length utilizing the root subsampling technique.

The subsampling technique (Eqs. [1 and 2]) was used for plants harvested 40, 80, and 120 DAT. Extensive root growth of overwintered plants harvested 369 DAT prevented identification of complete individual roots originating from the root collar. Thus, data for subsample root lengths and root areas and the respective root subsample fresh weights of plants harvested 120 DAT were substituted (Eqs. [1 and 2]) for estimating root areas and root lengths of plants harvested 369 DAT. Estimated root diameter was calculated as $\left\{\left[\right.\right.$ root area $\left(\mathrm{cm}^{2}\right)$ : root length $\left.\left.(\mathrm{cm})\right] / \pi\right\}$.

All plant tissues were dried at $70 \mathrm{C}$ for $72 \mathrm{~h}$ and weighed. Before drying, leaves and stems were washed and rinsed twice with distilled water while roots were washed in a solution of $0.1 \mathrm{~N} \mathrm{HCl}$, and rinsed twice with distilled water.

Dry weight $(\mathrm{g})$ and leaf area $\left(\mathrm{cm}^{2}\right)$ data from individual harvests were used to calculate specific leaf dry weight [SLW (leaf dry weight : leaf area)], root : shoot ratio \{RSR [root dry weight : shoot (leaf + stem) dry weight] $\}$, leaf weight ratio [LWR (leaf dry weight : total plant dry weight)], stem weight ratio [SWR (stem dry weight : total plant dry weight)], and root weight ratio [RWR (root dry weight : total plant dry weight)]. Relative growth rates (RGRs) for harvest intervals were determined for leaves, stems, and roots using the following general formulum where $\mathrm{W}_{1}$ and $\mathrm{W}_{2}$ are plant part dry weights at harvest times $\mathrm{t}_{1}$ and $\mathrm{t}_{2}$.

$$
\mathrm{RGR}=\left(\operatorname{In} \mathrm{W}_{2}-1 \mathrm{n} \mathrm{W}_{1}\right):\left(\mathrm{t}_{2}-\mathrm{t}_{1}\right)
$$

Mineral nutrient concentration was determined for samples collected on each of the five harvest dates $(0,40,80,120$, and 369 DAT). After drying, leaf, stem, and root tissues of five plants from each treatment were ground individually in a Wiley mill to pass a $0.425 \mathrm{~mm}$ (40 mesh) screen. Samples (1.25 g) were combusted at $490 \mathrm{C}$ for $6 \mathrm{~h}$. The resulting ash was dissolved in $10 \mathrm{ml} 6 \mathrm{~N} \mathrm{HCl}$ and 
adjusted to $50 \mathrm{ml}$ with deionized distilled water. Phosphorus, K, $\mathrm{Ca}, \mathrm{Mg}, \mathrm{Mn}, \mathrm{Cu}, \mathrm{Fe}, \mathrm{Zn}$, and $\mathrm{B}$ concentrations were determined by a inductively coupled plasma emission spectrophotometer (P2000; Perkin Elmer, Norwalk, Conn.). Nitrogen was determined using 10 -mg samples in aelemental analyzer (2400 CHN; Perkin Elmer). The 20 plants harvested at 0 DAT were analyzed similarly. Mineral nutrient content was based on the percentage concentration of a nutrient divided by 100 and multiplied by its respective plant part (leaf, stem, or root) dry weight. Mineral nutrient partitioning for N, $\mathrm{P}$, and $\mathrm{K}$ was based on plant part nutrient content divided by total plant nutrient content.

Experiment 2 (second outdoor container study). Procedures were identical to those employed for experiment 1 with the following exceptions. Rooted stem cuttings were potted 7 May 1992 and treatments applied 21 June 1992. Climatic conditions at the time of treatment were clear skies, a dry bulb temperature of $24.6 \mathrm{C}$, dewpoint of $18.5 \mathrm{C}$, and no wind. Fertilization (twice weekly) began on 12 May 1992, was reduced to a single weekly fertilization beginning 26 Sept., and was discontinued after 12 Oct. Primary, secondary, and tertiary stems were counted at each harvest. Nutrient concentration was not determined.

Data were subjected to analysis of variance (ANOVA) procedures (SAS Institute, Cary, N.C.) to test sources of experimental variation. No experiment (year) by uniconazole treatment interactions were present $(P \leq 0.05)$; therefore, all subsequent analyses were conducted on data representing a mean response for the two experiments. Significant differences among treatments $(P \leq 0.05)$ were found across and within harvest dates using ANOVA procedures. A planned orthogonal contrast to test for differences between a pooled uniconazole treatment effect and nontreated control $\left(0 \mathrm{mg} \cdot \mathrm{liter}^{-1}\right)$ was also conducted. Uniconazole concentration response $\left(0 \mathrm{mg} \cdot \mathrm{liter}^{-1}\right.$ excluded $)$ was analyzed by general linear regression analysis. All growth measurements were significantly $(P \leq 0.001)$ affected by time of harvest. A uniconazole by harvest date (DAT) interaction was present for all growth measurements with the exception of total leaf area, leaf dry weight, and primary stem number. Hence, data for all variables are presented by harvest date (DAT) except data for leaf area, leaf dry weight, and primary stem number which are a mean response across all harvest dates.

\section{Results and Discussion}

Uniconazole suppressed leaf area and leaf dry weight an average of $16 \%$ and $18 \%$, respectively, compared to nontreated controls ( $0 \mathrm{mg} \cdot$ liter $^{-1}$ uniconazole) (Table 1$)$, regardless of concentration (data not presented). While counting leaf number was not practical in this case, subsequent greenhouse experiments demonstrated leaf area suppression with no difference in leaf or node number following a foliar application of uniconazole at 170 mg.liter ${ }^{-1}$ (unpublished data). Furthermore, Viagro-Wolff and Warmund (1987) also reported no suppression of node number for container-grown 'Spectabilis' forsythia following a substrate drench application of uniconazole at $2.5 \mathrm{mg}$ a.i. / 3.1-liter pot. Similar suppression of leaf expansion for all plants receiving uniconazole, coupled with no differences in leaf or node number as noted in other experiments, suggests leaf area reduction may not result from a suppression of leaf production but a reduction in leaf expansion. However, Steinberg et al. (199 1) and Wang and Gregg (1989) reported drench applications of uniconazole suppressed leaf area of hibiscus (Hibiscus rosa-sinensis L.) by suppressing leaf production and leaf expansion. In the present study, specific leaf dry weight was $0.015 \mathrm{~g} \cdot \mathrm{cm}^{-2}$ for both uniconazole-treated and nontreated plants indicating uniconazole probably did not influ- ence forsythia leaf thickness. Specific leaf fresh weight data are presented in a companion paper and demonstrated a similar response (Thetford et al., 1995).

Degree of uniconazole suppression of stem and root dry weight differed with DAT (Table 1). Stem dry weight suppression was greatest at $80(47 \%)$ and 120 DAT $(46 \%)$ when stem dry weights decreased with increasing concentration of uniconazole (Tables 1 and 2). Stem dry weight was suppressed to a greater degree than leaf dry weight (18\%), a response consistent with previous research where leaf dry weight of 'Spectabilis' forsythia was suppressed $22 \%$ while stem dry weight was suppressed $48 \%$ when evaluated 100 days after uniconazole application (Warren et al., 1991). In the current experiments, the degree of stem dry weight suppression was $36 \%$ by 369 DAT. The greatest suppression of root dry weight was evident at 80 DAT (37\%) but decreased to $19 \%$ and 21\% 120and 369 DAT, respectively (Table 1).

Treatment with uniconazole suppressed root length from $15 \%$ to $36 \%$ and root area from $15 \%$ to $33 \%$ with the greatest suppression occurring 80 DAT (Table 1). The pattern of root length and root area suppression was reflective of decreased root dry weight. Root length and root area decreased with increasing concentration of uniconazole 80 DAT (Table 3) while the data also suggest a leveling off or decrease in the degree of suppression at 210 $\mathrm{mg} \cdot \mathrm{liter}^{-1}$ uniconazole. Estimated mean root diameter $(0.27 \mathrm{~cm})$ of forsythia was not influenced by uniconazole application. The effect of uniconazole on root growth has not been previously reported; however, paclobutrazol resulted in short roots (Rieger and Scalabrelli, 1990) with increased root tip diameter (Williamson et al., 1986) in peach. Suppression of root length or area following uniconazole application could reduce the potential for water and nutrient uptake in a landscape by limiting the volume of soil that can be exploited (Russell, 1977).

Uniconazole increased root : shoot ratios (RSRs) 40 DAT, similar to paclobutrazol-treated M.26 apple rootstocks (Atkinson and Crisp, 1982; Atkinson et al., 1982), suggesting root growth was favored over shoot growth (Table 1). Uniconazole decreased RSRs at 80 DAT but RSRs were not affected thereafter (data not presented), suggesting uniconazole suppression of root and shoot growth were similar in proportion regardless of concentration tested.

Uniconazole increased leaf weight ratios (LWRs) at 80 and 120 DAT compared to nontreated controls while stem weight ratios (SWRs) were decreased at all harvest dates (Table 1). Root weight ratios (RWRs) were not effected by uniconazole (data not presented). Based on RSR data alone, uniconazole did not influence carbon allocation beyond 80 DAT; however, LWR and SWR indicate carbon allocation was influenced within the shoot (leaf and stem) throughout the study.

Relative growth rates (RGRs) of uniconazole-treated leaves, stems, and roots decreased during the initial 40 DAT compared to the nontreated controls (Table 1). Stem and root RGR suppression continued into the second harvest interval (40-80 DAT) but no RGRs were suppressed after 80 DAT (data not presented) suggesting the principle period of uniconazole suppression occurred before 80 DAT. No difference in RGR after 80 DAT also suggests that uniconazole-treated plants will not have accelerated growth rates after the PGR effect has diminished.

Internode length decreased linearly with increasing uniconazole concentration 40, 80, and 120 DAT (Table 2) but new growth did not differ at 369 DAT with a mean length of $11.4 \mathrm{~mm}$. Similarly, Sterrett (1988) reported shoot growth of American sycamore (Platanus occidentalis L.) and yellow poplar (Liriodendron tulipifera L.) was suppressed with increasing concentration of 
Table 1. Effects of uniconazole on growth measurements of 'Spectabilis' forsythia across four harvest dates.

\begin{tabular}{|c|c|c|c|c|}
\hline Variable & $\mathrm{DAT}^{\mathrm{z}}$ & Nontreated ${ }^{y}$ & Uniconazole & Significance $^{x}$ \\
\hline Leaf area $\left(\mathrm{cm}^{2}\right)$ & All & 3245.9 & 2716.5 & 0.001 \\
\hline Leaf dry weight (g) & All & 47.9 & 39.3 & 0.001 \\
\hline \multirow[t]{4}{*}{ Stem dry weight $(\mathrm{g})$} & 40 & 9.4 & 6.3 & 0.001 \\
\hline & 80 & 16.2 & 8.6 & 0.001 \\
\hline & 120 & 25.6 & 14.0 & 0.001 \\
\hline & 369 & 61.4 & 39.1 & 0.001 \\
\hline \multirow[t]{4}{*}{ Root dry weight (g) } & 40 & 15.1 & 12.5 & 0.003 \\
\hline & 80 & 75.5 & 47.4 & 0.001 \\
\hline & 120 & 106.8 & 86.3 & 0.02 \\
\hline & 369 & 157.8 & 124.3 & 0.001 \\
\hline \multirow[t]{4}{*}{ Root length (m) } & 40 & 26.2 & 19.5 & 0.001 \\
\hline & 80 & 376.1 & 238.8 & 0.01 \\
\hline & 120 & 1202.6 & 955.7 & 0.05 \\
\hline & 369 & 5106.7 & 4355.7 & 0.05 \\
\hline \multirow[t]{4}{*}{ Root area $\left(\mathrm{m}^{2}\right)$} & 40 & 0.11 & 0.08 & 0.002 \\
\hline & 80 & 0.52 & 0.35 & 0.01 \\
\hline & 120 & 14.92 & 11.16 & 0.04 \\
\hline & 369 & 68.50 & 58.22 & 0.03 \\
\hline \multirow[t]{2}{*}{ Root : shoot ratiow } & 40 & 0.5 & 0.6 & 0.03 \\
\hline & 80 & 1.34 & 1.14 & 0.05 \\
\hline \multicolumn{5}{|l|}{ Dry weight ratio ${ }^{v}$} \\
\hline \multirow[t]{2}{*}{ Leaf weight ratio } & 80 & 0.31 & 0.38 & 0.02 \\
\hline & 120 & 0.30 & 0.32 & 0.04 \\
\hline Stem weight ratio & All & 0.17 & 0.13 & 0.001 \\
\hline \multicolumn{5}{|l|}{ Relative growth rate } \\
\hline Leaf & 40 & 2.38 & 2.15 & 0.001 \\
\hline \multirow[t]{2}{*}{ Stem } & 40 & 2.05 & 1.66 & 0.001 \\
\hline & 80 & 0.55 & 0.31 & 0.02 \\
\hline \multirow[t]{2}{*}{ Root } & 40 & 2.03 & 1.84 & 0.003 \\
\hline & 80 & 1.61 & 1.33 & 0.04 \\
\hline \multirow{3}{*}{$\begin{array}{l}\text { Internode diameter } \\
\quad(\mathrm{mm})\end{array}$} & 40 & 2.8 & 2.0 & 0.001 \\
\hline & 80 & 2.6 & 2.2 & 0.04 \\
\hline & 120 & 2.3 & 2.1 & 0.05 \\
\hline \multicolumn{5}{|l|}{ Stem number } \\
\hline Primary & All & 5.9 & 7.4 & 0.001 \\
\hline Secondary & 369 & 70.8 & 55.5 & 0.01 \\
\hline Tertiary & 369 & 47.7 & 33.0 & 0.01 \\
\hline \multicolumn{5}{|l|}{ Nitrogen partitioning ${ }^{\mathrm{t}}$} \\
\hline Leaf & 120 & 0.47 & 0.46 & NS \\
\hline Stem & 120 & 0.08 & 0.05 & 0.001 \\
\hline Root & 120 & 0.45 & 0.49 & NS \\
\hline
\end{tabular}

${ }^{2}$ Plants harvested 40, 80, 120, and 369 DAT.

Nontreated = control $\left(0 \mathrm{mg} \cdot \mathrm{liter}^{-1}\right.$ uniconazole $)$; uniconazole $=$ mean across all uniconazole concentrations $\left(90,120,170\right.$, and $\left.210 \mathrm{mg} \cdot \operatorname{liter}^{-1}\right)$ for a given harvest date $(40,80,120$ or 369) or across all harvest dates (all) where appropriate.

${ }^{x}$ Orthogonal contrast $=$ nontreated vs. uniconazole-treated.

"Root : shoot ratio = Root dry weight : shoot (leaf and stem) dry weight.

'Dry weight ratio = plant part dry weight : total plant dry weight.

"Relative growth rate $=\left(1_{\mathrm{n}} \mathrm{W}_{2}-1_{\mathrm{n}} \mathrm{W}_{1}\right):\left(\mathrm{t}_{2}-\mathrm{t}_{1}\right)$ where $\mathrm{W}_{1}$ and $\mathrm{W}_{2}$ are plant part dry weights $(\mathrm{g})$ at times $\mathrm{t}_{1}$ and $\mathrm{t}_{2}$.

'Nitrogen partitioning = plant part $\mathrm{N}$ content : total plant $\mathrm{N}$ content.

uniconazole the first growing season but no inhibition was present during the second growing season. Diameter of these same internodes was also suppressed $29 \%, 14 \%$, and $5 \%$ at 40,80 , and 120 DAT, respectively (Table 1). Wang and Gregg (1989) reported similar results with 'Jane Cowl' hibiscus. Suppression of internode length and diameter during the growing season was probably the dominant factor suppressing stem dry weight throughout the test period. Length and diameter of the most recently matured internodes were not significantly affected by uniconazole 369 DAT (data not presented). This pattern of internode suppression suggests uniconazole can provide height control during the production of woody ornamental species without substantial suppression of subsequent growth once planted in the landscape the following season. However, the morphological-anatomical changes associ- 
Table 2. Stem dry weight and internode length of 'Spectabilis' forsythia after uniconazole application.

\begin{tabular}{|c|c|c|c|c|c|}
\hline \multirow{3}{*}{$\begin{array}{l}\text { Uniconazole } \\
\left.\text { (mg.liter }{ }^{-1}\right)\end{array}$} & \multicolumn{2}{|c|}{ Stem dry wt (g) } & \multicolumn{3}{|c|}{ Internode length (mm) } \\
\hline & \multicolumn{5}{|c|}{ Days after treatment } \\
\hline & 80 & 120 & 40 & 80 & 120 \\
\hline$\overline{0}$ & 16.2 & 25.6 & 30.5 & 28.9 & 23.6 \\
\hline 90 & 9.4 & 17.4 & 11.8 & 17.8 & 20.0 \\
\hline 130 & 8.7 & 13.6 & 10.5 & 18.1 & 17.4 \\
\hline 170 & 8.3 & 12.3 & 9.0 & 17.5 & 16.6 \\
\hline 210 & 8.1 & 12.6 & 7.7 & 14.9 & 14.9 \\
\hline \multicolumn{6}{|l|}{ Significance } \\
\hline \multicolumn{6}{|l|}{ Uniconazole $e^{z}$} \\
\hline Linear & NS & NS & 0.001 & 0.05 & 0.01 \\
\hline Quadratic & 0.004 & 0.04 & NS & NS & NS \\
\hline
\end{tabular}

${ }^{2}$ Control $\left(0 \mathrm{mg} \cdot\right.$ liter $\left.^{-1}\right)$ excluded from regression analysis.

${ }^{\mathrm{Ns}}$ Nonsignificant at $\mathrm{P}>0.05$.

ated with this decrease in internode length and diameter should be considered since these stems will provide the framework for all future growth (Thetford, et al., 1995).

Uniconazole increased primary stem number by $20 \%$ at all harvest dates and suppressed secondary and tertiary stem number 369 DAT (Table 1). Secondary and tertiary stem number were not influenced prior to winter dormancy (data not presented). However, the increase in primary stem numbers combined with the decrease in internode length and diameter for uniconazole-treated plants provided a smaller framework of branches from which secondary and tertiary branches could develop the following spring. Even though the number of secondary and tertiary branches were decreased by uniconazole, the uniconazole-treated plants appeared to have a denser plant canopy compared to the controls (personal observations), likely a result of suppressed internode length. Such changes in branch distribution may influence other growth factors such as flowering.

Mineral nutrient content, concentration, and partitioning were not influenced by uniconazole concentration $\left(0 \mathrm{mg} \cdot \mathrm{liter}^{-1} \mathrm{ex}^{-}\right.$ cluded). Hence, data for all uniconazole treatments were pooled and resulting means compared to the nontreated controls. Uniconazole affected mineral nutrient content and concentration similarly at all harvest dates; therefore, only nutrient concentration
Table 3. Root length, root area, and root : shoot ratios of 'Spectabilis' forsythia 80 days after uniconazole application.

\begin{tabular}{lccc}
\hline $\begin{array}{l}\text { Uniconazole } \\
\left(\mathrm{mg} \cdot \text { liter }^{-1}\right)\end{array}$ & Root length $(\mathrm{m})$ & Root area $\left(\mathrm{m}^{2}\right)$ & Root : shoot ratio \\
\hline 0 & 376.1 & 0.52 & 1.34 \\
90 & 236.8 & 0.35 & 1.09 \\
130 & 245.2 & 0.34 & 1.24 \\
170 & 261.0 & 0.37 & 1.21 \\
210 & 212.2 & 0.32 & 1.00 \\
Significance & & & \\
$\quad$ Uniconazole & & & \\
$\quad$ Linear & 0.001 & 0.001 & $\mathrm{NS}$ \\
$\quad$ Quadratic & $\mathrm{NS}$ & $\mathrm{NS}$ & 0.03 \\
\hline
\end{tabular}

${ }^{2}$ Control $\left(0 \mathrm{mg} \cdot\right.$ liter $\left.^{-1}\right)$ excluded from regression analysis,

${ }^{\mathrm{N} S}$ Nonsignificant at $P>0.05$.

and partitioning data for 120 DAT are presented (Tables 1 and 4). In addition, only $\mathrm{N}$ is presented for mineral nutrient partitioning since $\mathrm{N}$ partitioning responses were similar to all other nutrients. Since nutrient concentration and nutrient content were affected similarly, these results are not a result of dilution due to differences in dry weight production. Uniconazole increased leaf $\mathrm{N}, \mathrm{P}, \mathrm{Mg}, \mathrm{Zn}$, and $\mathrm{B}$ concentrations while leaf $\mathrm{K}, \mathrm{Ca}, \mathrm{Fe}, \mathrm{Cu}$, and $\mathrm{Mn}$ concentrations were not affected (Table 4). No leaf mineral nutrient concentrations were suppressed by uniconazole and the proportion of total $\mathrm{N}$ allocated to the leaves did not differ with uniconazole application (Table 1). Addition of paclobutrazol to a nutrient solution culture increased leaf $\mathrm{N}, \mathrm{P}, \mathrm{K}, \mathrm{Ca}$, and $\mathrm{Mg}$ concentration in apple (Wang et al., 1985). Soil application of paclobutrazol to containergrown apple trees, however, lowered leaf $\mathrm{K}$ concentration (Atkinson, 1986; Atkinson and Crisp, 1982; Swietlik and Miller, 1985; Wieland and Wample, 1985) while leaf concentrations of $\mathrm{N}$ and $\mathrm{P}$ were variable within these experiments. With the exception of stem Mn concentration, stem nutrient concentrations were higher for uniconazole-treated plants than the nontreated controls. The proportion of total $\mathrm{N}$ allocated to stems decreased with uniconazole application compared to the controls (Table 1); a response consistent with changes in stem dry weight and SWRs which were affected to a greater degree than leaves or roots. Uniconazole resulted in greater root $\mathrm{N}, \mathrm{P}, \mathrm{K}, \mathrm{Cu}$, and $\mathrm{Mn}$ concentrations while root $\mathrm{Ca}, \mathrm{Mg}, \mathrm{Fe}, \mathrm{Zn}$, and $\mathrm{B}$ concentrations and the

Table 4. Effect of uniconazole on the mineral nutrient concentration in leaves, stems, and roots of 'Spectabilis' forsythia 120 days after uniconazole application.

\begin{tabular}{|c|c|c|c|c|c|c|c|c|c|c|c|c|}
\hline \multirow{2}{*}{$\begin{array}{l}\text { Mineral } \\
\text { nutrient }^{z}\end{array}$} & \multicolumn{4}{|c|}{ Leaf } & \multicolumn{4}{|c|}{ Stem } & \multicolumn{4}{|c|}{ Root } \\
\hline & Initial $^{y}$ & Nontreat & $\mathrm{ed}^{\mathrm{x}}$ & Treated & Initial & Nontreated & & Treated & Initial & Nontreate & & Treated \\
\hline $\mathbf{N}$ & 2.93 & $2.00^{\mathrm{w}}$ & 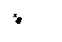 & 2.05 & 1.02 & 0.72 & & 0.92 & 2.23 & 0.92 & & 1.18 \\
\hline $\mathbf{P}$ & 0.25 & 0.15 & & 0.16 & 0.17 & 0.11 & & 0.13 & 0.22 & 0.15 & & 0.19 \\
\hline $\mathbf{K}$ & 1.69 & 1.35 & NS & 1.29 & 1.24 & 0.90 & & 1.03 & 1.73 & 1.10 & & 1.13 \\
\hline $\mathrm{Ca}$ & 0.58 & 0.79 & NS & 0.76 & 0.22 & 0.24 & & 0.29 & 0.14 & 0.22 & NS & 0.22 \\
\hline $\mathrm{Mg}$ & 0.34 & 0.17 & & 0.20 & 0.16 & 0.11 & & 0.12 & 0.21 & 0.12 & NS & 0.12 \\
\hline $\mathrm{Fe}$ & 137.0 & 96.0 & NS & 99.0 & 70.0 & 68.0 & & 110.0 & 233.0 & 464.0 & NS & 443.0 \\
\hline $\mathrm{Cu}$ & 8.9 & 1.4 & NS & 1.6 & 9.9 & 2.1 & & 2.6 & 10.3 & 2.0 & & 2.2 \\
\hline $\mathrm{Mn}$ & 481.0 & 414.0 & NS & 379.0 & 53.0 & 67.0 & NS & 73.0 & 33.0 & 22.0 & & 26.0 \\
\hline $\mathrm{Zn}$ & 45.8 & 6.8 & & 7.9 & 59.2 & 11.6 & & 21.0 & 161.0 & $7.6 \mathrm{NS}$ & & 7.1 \\
\hline B & 47.4 & 34.2 & & 38.0 & 13.8 & 13.4 & & 14.9 & 10.0 & $8.2 \mathrm{NS}$ & & 7.9 \\
\hline
\end{tabular}

${ }^{\overline{\mathrm{N}}} \mathrm{N}, \mathrm{P}, \mathrm{K}, \mathrm{Ca}$, and $\mathrm{Mg}$ are expressed in percent dry weight. Fe, $\mathrm{Cu}, \mathrm{Mn}, \mathrm{Zn}$, and $\mathrm{B}$ are expressed in mg.g ${ }^{-1}$ dry weight.

${ }^{y}$ Initial nutrient concentration at treatment initiation ( 0 days after treatment).

${ }^{x}$ Nontreated $=$ control $\left(0 \mathrm{mg} \cdot \mathrm{liter}^{-1}\right.$ uniconazole $)$; treated $=$ mean across all uniconazole concentrations $\left(90,130\right.$, 170 , and $210 \mathrm{mg} \cdot 1$ iter $\left.{ }^{-1}\right)$.

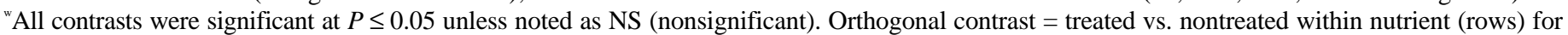
a given plant part. 
proportion of total $\mathrm{N}$ allocated to the roots were not affected (Table 4). Even though root length and root area were suppressed by uniconazole application, nutrient absorption was similar or greater throughout the experiment for uniconazole-treated plants compared to controls. This suggests plants would not experience mineral nutrient deficiency when transplanted into the landscape provided sufficient nutrients are available. Uniconazole generally resulted in increased mineral nutrient concentration compared to the controls, indicating uptake of nutrients was not impaired.

Results suggest that within the concentrations tested, the principle means of growth suppression in 'Spectabilis' forsythia by uniconazole is suppression of internode elongation which continues for a single growing season and overall suppression of size is proportional between the roots and shoots after 80 DAT. With a single foliar application of uniconazole, short and compact container-grown forsythia with root : shoot ratios similar to nontreated plants can be produced without labor intensive pruning.

\section{Literature Cited}

Atkinson, D. 1986. Effects of some plant growth regulators on water use and the uptake of mineral nutrients by tree crops. Acta Hort. 179:395404.

Atkinson, D. and C.M. Crisp. 1982. Prospects for manipulating tree root systems using plant growth regulators: Some preliminary results. Proc. 1982 Brit. Crop Protection Conf. Weeds 4593-599.

Atkinson,D.,C.M. Crisp,G.W.F. Sewel1,S.A. Wilson,T.E.O. Asamoah, and G.C. White. 1982. Effects of growth regulators on root growth and morphology. Rpt. East Malling Res. Sta. 1981. p. 30-32.

Bailey, D.A. and W.B. Miller. 1989. Whole-plant response of Easter lilies to ancymidol and uniconazole. J. Amer. Soc. Hort. Sci. 114:393-396.

Davis, T.D., G.L. Steffens, and N. Sankhla. 1988. Triazole plant growth regulators. Hort. Rev. 10:63-105.

Fletcher, R.A. and G. Hofstra. 1985. Triadimefon- A plant multiprotectant. Plant Cell Physiol. 26:775-780.

Izumi, K., I. Yamaguchi, A. Wada, H. Oshio, and N. Takahashi. 1984. Effects of a new plant growth retardant (E)-1-(4-Chlorophenyl)-4,4dimethyl-2-(1,2,4-triazol-1-yl)-1-penten-3-01 (S-3307) on the growth and gibberellin content of rice plants. Plant Cell Physiol. 25:611-617.

Keever, G.J. and M.S. West. 1992. Response of established landscape plants to uniconazole. HortTechnology 2:465-468.

Norcini, J.G. and G.W. Knox. 1989. Response of Ligustrum x ibolium, Photinia $\times$ frazeri and Pyracantha koidzumii 'Wonderberry' to XE-
1019, and pruning. J. Environ. Hort. 7:126-128.

Reed, A.N., E.A. Curry, and M.W. Williams. 1989. Translocation of triazole growth retardants in plant tissues. J. Amer. Soc. Hort. Sci. 114:893-898.

Rieger, M. and G. Scalabrelli. 1990. Paclobutrazol, root growth, hydraulic conductivity, and nutrient uptake of 'Nemaguard' peach. HortScience 25:95-98.

Russell, R.S. 1977. Plant root systems. McGraw-Hill, London.

Steffens, G.L. 1988. Gibberellin biosynthesis inhibitors: Comparing growthretarding effectiveness on apple. J. Plant Growth Regulat. 7:27-36.

Steffens, G.L., J.K. Byun, and S.Y. Wang. 1983. Gibberellin biosynthesis inhibitors: Comparing growth retarding effectiveness on apple. J. Plant Growth Regulat. 7:27-36.

Steinberg, S.L., J.M. Zajicek, and M.J. McFarland. 1991. Water relations of hibiscus following pruning or chemical growth regulation. J. Amer. Soc. Hort. Sci. 116:465-470.

Sterrett, J.P. 1988. XE-1019: Plant response, translocation and metabolism. J. Plant Growth Regulat. 7: 19-26.

Swietlik, D. and S.S. Miller. 1985. The effect of paclobutrazol on mineral nutrition of apple seedlings. J. Plant Nutr. 8:369-382.

Thetford M., S.L. Warren, F.A. Blazich, and J. F. Thomas. 1995. Response of Forsythia x intermedia 'Spectabilis' to uniconazole: II. Leaf and stem anatomy, chlorophyll, and photosynthesis. J. Amer. Soc. Hort. Sci. 120:983-988.

Viagro-Wolff, A.L. and M.R. Warmund. 1987. Suppression of growth and plant moisture stress of forsythia with flurprimidol and XE-1019. HortScience 22:884-885.

Wang, S.Y., J.K. Byun, and G.L. Steffens. 1985. Controlling plant growth via the gibberellin biosynthesis system-II. Biochemical and physiological alterations in apple seedlings. Physiol. Plant. 63:169-175.

Wang, Y.-T. and L.L. Gregg. 1989. Uniconazole affects vegetative growth, flowering and stem anatomy of hibiscus. J. Amer. Soc. Hort. Sci. 114:927-932.

Warren, S.L. 1990. Growth response of 13 container-grown landscape plants to uniconazole. J. Environ. Hort. 8:151-153.

Warren, S.L., F.A. Blazich, and M. Thetford. 199 1. Whole-plant response of selected woody landscape species to uniconazole. J. Environ. Hort. 9:163-167.

Wieland, W.F. and R.L. Wample. 1985. Root growth, water relations and mineral uptake of young 'Delicious' apple trees treated with soil and stem-applied paclobutrazol. Scientia Hort. 26:129-137.

Williamson, J.G., D.C. Coston, and L.W. Grimes. 1986. Growth responses of peach roots and shoots to soil and foliar-applied paclobutrazol. HortScience 21:1001-1003. 